\title{
A REVIEW ON CURRENT PRACTICES OF PLASTICS WASTE MANAGEMENT AND FUTURE PROSPECTS
}

\author{
Netra Lal Bhandari ${ }^{1 *}$, Sulakshana Bhattarai ${ }^{1}$, Ganesh Bhandari $^{1}$, Sumita Subedi ${ }^{2}$, Kedar Nath Dhakal ${ }^{3}$ \\ ${ }^{1}$ Department of Chemistry, Tri-Chandra Multiple Campus, Tribhuvan University, Kathmandu, Nepal \\ ${ }^{2}$ Department of Chemistry and Chemical Engineering, Inha University, Incheon, South Korea \\ ${ }^{3}$ Central Department of Chemistry, Tribhuvan University, Kirtipur, Nepal \\ *Corresponding author: netra.tu.edu@gmail.com
}

(Received: November 02, 2020; Revised: January 09, 2021; Re-revised: May 11, 2021; Accepted: June 08, 2021)

\begin{abstract}
Inefficient solid waste management of plastics and polymeric materials is one of the global challenges leading to environmental deterioration. This challenge has brought alarming concern to minimize volume of such wastes released into the environment. The concern proposes a solution to the existing problems to some extent by reuse, recycling, and efficient conversion of waste materials into alternative application. Chemical and thermo-mechanical conversion of plastic wastes into energy and their biodegradation were taken into account. Consequently, some newly employed recycling and conversion techniques of plastic wastes, and possible future alternatives with recommendations are reviewed in this article.
\end{abstract}

Keywords: Plastic wastes, environmental concern, recycling, conversion, degradable materials.

\section{INTRODUCTION}

Synthetic and natural materials with carbon as an element that are composed of high-molecular-weight chains are the plastics, which was invented by Alexander Parkes in 1862 (Horodytska et al., 2018). These synthetic polymers or semi-synthetic organic materials uses are rapidly increasing in our daily life. Improper management of plastics causes problems in many sectors including environment leading to global warming (Hoornweg \& Bhadatata, 2015). Due to their lightweight, durability, and versatility, they find a diverse range of applications such as various household appliances, corrosion-protected pipelines, furniture, packaging materials, containers, automobile and aircraft parts, 3D printing (Azeez, 2018), bio-adsorbents (Pokhrel et al., 2019; Shrestha et al., 2019), for medical purposes (Phaiju et al., 2020), etc. Such applications of plastics and polymers led to their increased daily use in different forms and models.

The global plastic production increased by 250 million tons per year from 2009 to 2010 (Pandey et al., 2016), which was increased to 320 million tons per annum in 2016 (Drzyzga \& Prieto, 2018). China and European countries accounted for about $45 \%$ of the global plastics production (i.e., $23.5 \%$ and $21.5 \%$, respectively) in 2010 (Nath, 2014). According to the ICIMOD (2018), Nepal produces about 2.7 tons of plastic garbage daily, and its improper management creates lots of problems including environmental pollution.

Only one-third of the total plastic wastes generated are suitable for recycling, based on their material composition (Chamas et al., 2020). Polypropylene (PP), polyethylene (PE), polystyrene (PS), polyvinyl chloride (PVC), etc. are some of the recyclable plastics (SWMRMC/UNHABITAT, 2008). However, most of the plastic wastes are incinerated at dumping sites (Rigamonti et al., 2014). The debris can primarily be obtained from the large plastic processing and manufacturing industries, while commercial wastes are often produced from workshops, craftsmen shops, supermarkets, and wholesalers.

\section{Some methods of plastic waste management}

The uses of plastics are increasing day by day, and there is no solo method of their reuse, and disposal (Beyene, 2014; Dhokhikah \& Trihadiningrum, 2012). The approach of management depends on the nature of plastics, and various countries have been practicing different methods. During the end of $20^{\text {th }}$ century, China started buying plastic wastes for recycling purposes (Goncalves, 2018). In Austria, about 763,500 tons of plastic wastes were handled in 1994, and about $75 \%$ of the amounts were buried in controlled landfills (Braunegg et al., 2004). America, Canada, Germany, and Bangaladesh are working for sustainable plastic waste management using landfilling, biological degradation, composting, and chemical degradation (Shah, 2008).

Nowadays, the use of different additives and hardeners with plastics decreases their biodegradability. Various countries have been practicing different approaches for solid plastic waste management, but none of these approaches are energy efficient and sustainable. It leads the undeveloped and developing countries manage their plastic wastes employing costly recycling or pyrolysis (catalytic and non-catalytic) processes. Nepal is following landfilling or dumping method (ICIMOD, 2018) to date and in the search of alternatives. It is an urgent need to collect plastics separately, unglued from other wastes such 
as glasses, metals (electrical stuffs/electronics), and compostable solids, as practiced in developed countries.

\section{Landfilling}

Typically, 5 to $25 \%$ (by weight) of plastic wastes is assumed to be potential for recycling purposes. However, information about the opportunities and challenges of plastic recovery, and recycling from the landfill sites are still missing (Cherubini et al., 2009). Although a large fraction of the plastic wastes are subjected to landfill, such disposal is undesirable due to high cost, generation of greenhouse gases (methane, carbon monoxide, hydrogen sulfide, etc.), and poor degradability (Canopoli et al., 2018). Uncontrolled fires and toxic emissions are common problems with poorly managed landfill sites that are considered as one of the sources of environmental pollution (Hidayah \& Syafrudin, 2018).

Landfills are not the option with a complete solution of plastic waste management, though it provides disposal space for the residues and non-treatable solid wastes. In Nepal, the landfilling is a common process of the solid waste management. Okharpauwa landfill site at Nuwakot and Teku landfill site in Kathmandu are the major landfill sites in Nepal (ICIMOD, 2018). However, the management of such sites seems poor (Fig. 1), which badly affects in human respiration, optical vision, and skin allergy problems (Matlack, 2001). Additionally, the landfill areas/sites are inappropriate for construction works for about 50 years (ICIMOD, 2018).

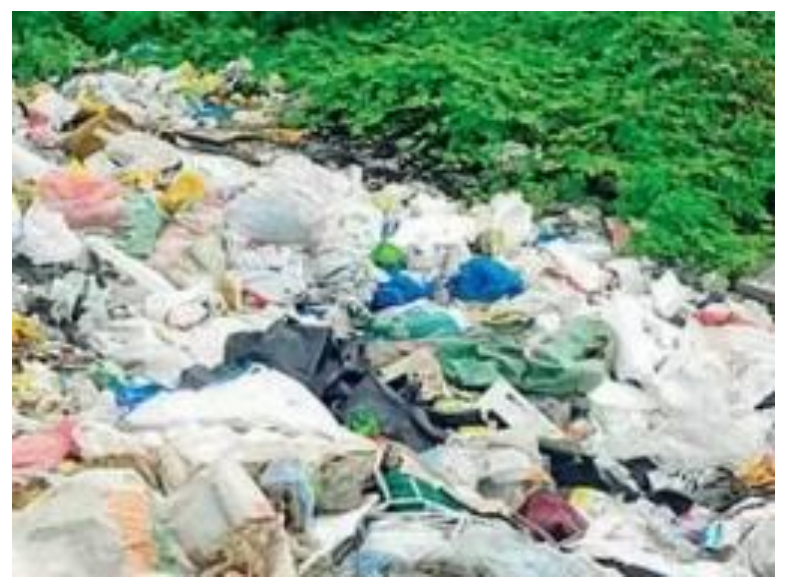

Fig. 1. Photograph of one of the landfill sites in Nepal

\section{A mechanical method of recycling}

Mechanical recycling is a method of re-processing plastic wastes employing comparatively high energy along with additives producing recycled product (Ejlertsson et al., 2003; Klink \& Ham, 1982; Scaffaro et al., 2019). This method comprises of collection, sorting out, and reprocessing of polymers into recycled products. Recycling of polyethylene terephthalate (PET) can be employed because the recycling rate of PET is higher in comparison to other plastics (such as high-density polyethylene (HDPE), low-density polyethylene (LDPE), polypropylene (PP), etc.) recycled by this method (Hopewell et al., 2009; Lu et al., 2012).

Different spectroscopic and X-ray techniques are applied to sort out the plastic wastes (Ragaert et al., 2017). Various procedures of recycling are adopted based on the origin and composition of the waste materials. It makes method of recycling comparatively expensive (Ragaert $e t$ $a l ., 2017)$. The crude shredder reduces the products to fistsized particles, rotating drum washer, and fine shredder from washing reduces further in small-sized granules that are processed for further applications. The flow chart of the representative plant with the working principle of the mechanical recycling procedure is shown in Fig. 2. The float-sink separation, mechanical drier, and melt filter regranulation work to separate PP and PE as float, and the other polymers such as PET, PS, and PVC as a sink in this method (Scaffaro et al., 2019; Ragaert et al., 2017).

\section{Thermal recycling/pyrolysis}

Thermal/pyrolytic recycling is an alternative method for plastics waste management. Although the chlorine content in PVC and other plastics is responsible for the formation of dioxins and furans during thermal recycling, the relationship between plastics fed into an incinerator and the generation of dioxins and furans is still unclear (Yang et al., 2001; Miskkolczi et al., 2004). The recycled PVC waste is used in plumbing pipes and fittings (Azeez, 2018). The sheets of PVC waste after thermal recycling are also used in various fields such as blister packages, packaging, construction, human rehabilitation, electronics, food trays, household applications, automotive and aerospace components, etc. (Azeez, 2018).

Thermal degradation of the polymeric materials which is also called thermal cracking or pyrolysis occurs in the absence or presence of oxygen (Alla et al., 2014; Arandes et al., 2003; Walendziewski \& Steiningr, 2001; Demirbas, 2004; Panda et al., 2010). This process is carried out at temperatures between 350 to $900^{\circ} \mathrm{C}$. Hydrocarbon oils consisting of paraffin, isoparaffins, olefins, naphthenes, and aromatic compounds are produced from the process, however, no condensable high calorific value gas during this process (Niziolek et al., 2017). It can also be carried out in presence of a catalyst (Al-Salem et al., 2017; Iwaya et al., 2002) with lower reaction temperatures (Gulab et al., 2010). This advantage is further supported by comparative data of thermal and catalytic pyrolysis of microcrystalline zeolites presented in Table 1 (Almeida \& Marques, 2016).

The commonly used catalysts in plastic waste pyrolysis include silica-alumina (Qiu et al., 2017), zeolites (Cunliffe et al., 2002), and MCM-41 (Marcilla et al., 2003). Among numerous zeolites investigated in 
polyolefin pyrolysis, Beta (He et al., 2009), ultrastable Ytype (USY) (Boxiong et al., 2007), ZSM-11(Balasundram et al., 2018) REY amorphous silica-alumina (ASA) (Zabeti et al., 2012), Brookhart's iridium (III) (Monsigny et al., 2019) are frequently used. The pyrolysis process of the polypropylene at the temperature of $450^{\circ} \mathrm{C}$ and pressure of $5 \mathrm{kgf} / \mathrm{cm}^{2}$ is shown in Fig. 3.

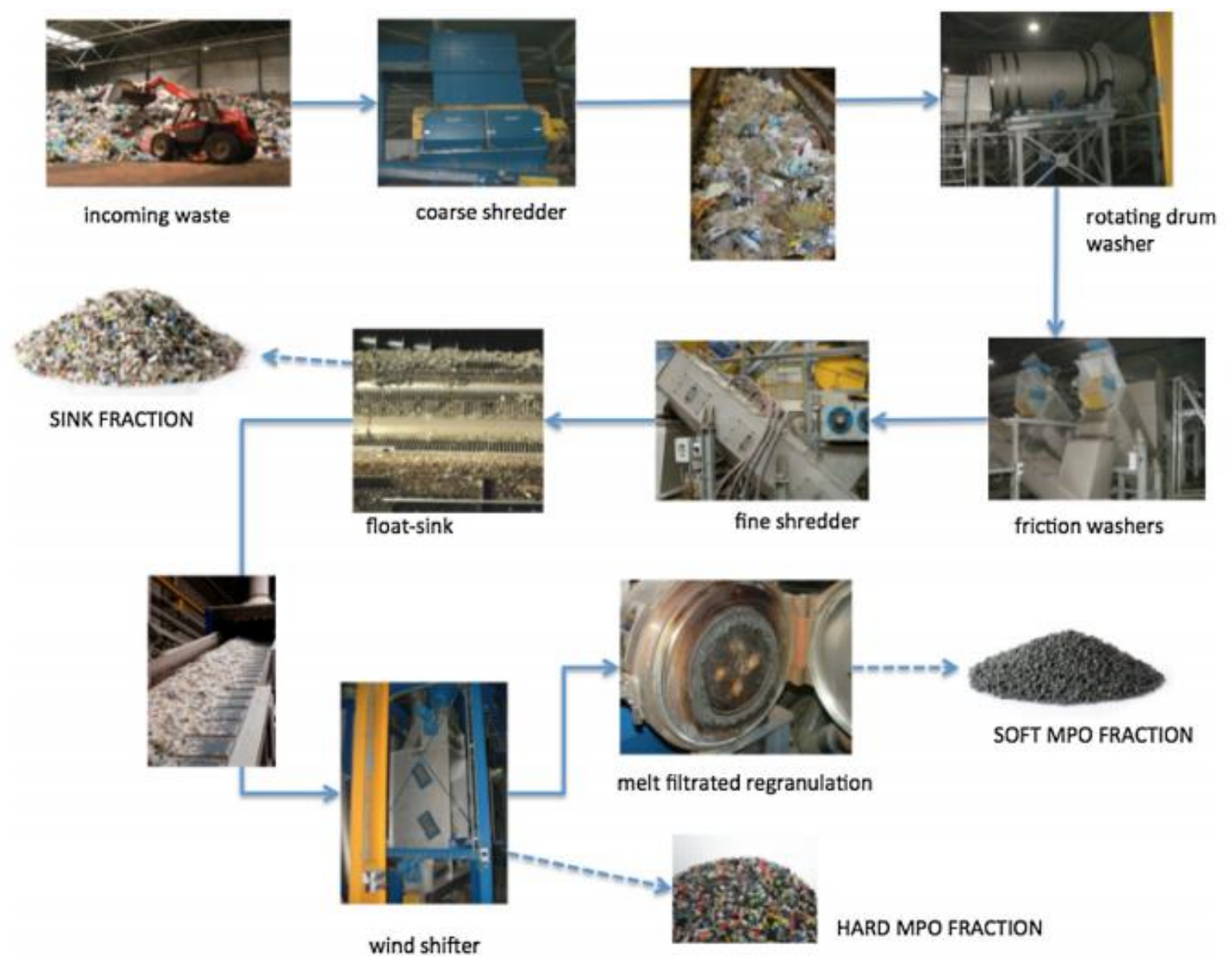

Fig. 2. The schematic flow chart illustrating the working principle of mechanical recycling (Ragaert et al., 2017)

Table 1. Yield in thermal and catalytic pyrolysis of microcrystalline zeolite (ZSM-5)*

\begin{tabular}{lcc}
\hline $\begin{array}{c}\text { Production yield } \\
\text { (\% wt.) }\end{array}$ & $\begin{array}{c}\text { Thermal } \\
\text { pyrolysis }\end{array}$ & $\begin{array}{c}\text { Catalytic } \\
\text { pyrolysis }\end{array}$ \\
\hline Gas fraction & 13.0 & 63.5 \\
Liquid fraction total & 84.0 & 35.0 \\
$\mathrm{C}_{6-} \mathrm{C}_{12}$ & 56.55 & 99.92 \\
$\mathrm{C}_{13} \mathrm{C}_{23}$ & 37.79 & 0.08 \\
$\mathrm{C}_{23}$ & 5.66 & 0.0 \\
Solid fraction & 3.0 & 1.5 \\
Source: Almeida \& Marques (2016) &
\end{tabular}

Similarly, the percentage of oil and wax obtained, reaction time, and calorific value of oil is shown in Table 2 (Sonawane et al., 2015). It shows a lower calorific value and the yield of oil in comparison to natural zeolite as a catalyst (Sonawane et al., 2015). The time required for the pyrolysis of polymers in presence of natural zeolite is lower in comparison to its absence (65 $\mathrm{min}$ for catalyst and 90 min without catalyst) (Sonawane et al., 2015).

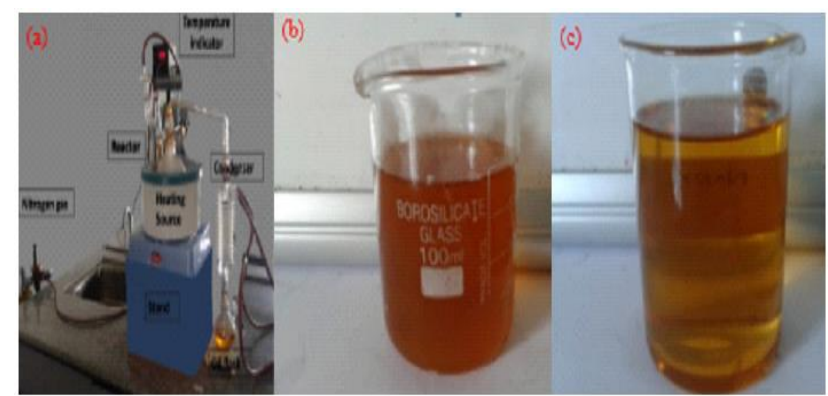

Fig. 3. (a) Experimental set up for pyrolysis of polypropylene (b) Oil obtained from pyrolysis without catalyst (c) Oil obtained from pyrolysis with $10 \%$ natural zeolite as a catalyst (Sonawane et al., 2015) 


\section{Chemical recycling}

In this method, polymers are converted into their corresponding monomers (Achilias et al., 2007) which are utilized as a feedstock for a variety of downstream industrial processes and as transportation fuels. It involves three different processes such as depolymerization, partial oxidation, and chemical cracking for recycling (Cunliffe et al., 2003). In depolymerization, polymeric wastes are converted into sulfur-free liquid energy carriers by chemical recycling (Aguado et al., 1999). These installations (80-85\%) allow the recovery of the energy contain in the plastic wastes. It is reported that $1 \mathrm{mg}$ of depolymerized products of mixed plastics can carry 4.5 to

5.9 calories of energy. Hence, this technology of conversion of plastics into alternative fuels is considered as a high-efficiency value and eco-friendly technology (Woloseiwicz-Glab et al., 2017; Sakata et al., 1999). Condensation polymers such as polyamides, polyesters, nylons, polyethylene, terephthalate, etc. can be depolymerized via reversible synthesis reactions to initial di-acids and diols or diamines (Shabtai et al., 1997). The polymers are converted into their raw monomers via depolymerization reactions such as alcoholysis, glycolysis, and hydrolysis, etc. (Kaminsky \& Zorriqueta, 2007).

Table 2. Percentage yield of oil and wax obtained without catalyst and $\mathbf{1 0 \%}$ natural zeolite (Sonawane et al., 2015)

\begin{tabular}{lllll}
\hline PP material $(\mathbf{2 0 0} \mathbf{g})$ & Oil $(\boldsymbol{\%})$ & Wax $(\boldsymbol{\%})$ & Reaction time (minutes) & Calorific value of oil $(\mathbf{K J} / \mathbf{K g})$ \\
\hline Without catalyst & 80.82 & 18.64 & 90 & 25794 \\
With 10 \% Nz catalyst & 86.41 & 11.34 & 65 & 27167 \\
\hline
\end{tabular}

Partial oxidation takes place in presence of oxygen or steam during which polymer wastes undergo combustion followed by the formation of light hydrocarbons, oxides of nitrogen, sulfur oxides, and dioxins (Shabtai et al., 1997). Similarly, other cracking processes such as hydrocracking, thermal cracking, and catalytic cracking are also reported (Beneroso et al., 2015). Typical feeds used in them include polyethylene, polyethylene terephthalate, polystyrene, polyvinyl chloride, and mixed polymers, polymer waste from municipal solid waste and other sources, polymers-coal co-mixture, refinery oilscoal (alone or co-processed) mixture, etc. (Dwivedi et al., 2019).

\section{Biological recycling}

Biological recycling is the process in which microorganisms (bacteria, actinomycetes, and fungi) degrade the plastics, and waste polymeric materials producing $\mathrm{CO}_{2}, \mathrm{H}_{2} \mathrm{O}$, and microbial biomass, as the final products (Labelagr, 2006; Kujawa et al., 2007, Cerqueira et al., 2016). Dominant groups of microorganisms and the different pathways (aerobic and anaerobic) associated with polymer degradation are often determined by the environmental conditions (Fesseha \& Abebe, 2019; Singh \& Rawat, 2019). The microorganisms such as Grampositive and Gram-negative bacteria as well as a few species of fungal origin like Aspergillus are particularly involved. Species of microbes like Streptococcus, Staphylococcus, Micrococcus (Gram-positive), Moraxella and Pseudomonas (Gram-negative), and species of fungi (Aspergillus glaucus and Aspergillus niger) are associated with biodegradation of plastics. Besides Pseudomonas fluorescens B-22, Phanerochaete chrysosporium, Rhodococcus ruber, Penicillium oxalicum, Bacillus cereus, etc., are involved in breaking down the plastics/polymers such as polyvinyl chloride, nylon, polystyrene, polyethylene, and polypropylene respectively (Danko et al., 2004; Iiyoshi et al., 1998; Mor \& Sivan, 2008; Ojha et al., 2017; Helen et al., 2017).

Biodegradation and composting are also used almost as a synonymous terms in biological recycling but not the same, and the exact mechanism of biological recycling is still unknown and yet to be optimized. Although there are many possible predicted mechanisms of bio-recycling, a simple one is shown in Fig. 4 (Fesseha \& Abebe, 2019). During biological recycling of polymeric solid waste products, the formation of methane, $\mathrm{CO}_{2}, \mathrm{H}_{2} \mathrm{O}$, metabolic products such as sugars, etc., are commonly formed which are useful for plant growth. The composted final products of waste plastics are used as fertilizers. Bio-based plastics such as poly-lactic acid, polyesters, polyhydroxy butyrate, etc., are hydrolyzed and degraded more easily as compared to petro-based plastics such as polyethylene, polystyrene, polypropylene, etc. Hence, the research on bio-based polymeric materials with their end products as fertilizers has flourished in recent years (Fesseha \& Abebe, 2019; Ciriminna \& Pagliaro, 2020).

The microorganisms such as Comamonas acidovorans, Fusarium solani, Phanerochaete chrysosporium contribut to degradation of plastics in presence of enzymes such as lipases, cutinase, and manganese peroxide (Table 3). Plastics undergo biodegradation producing biofilms, oligomers, monomers, and substrates. Some plastics and corresponding degrading microorganisms are presented in Table 3. Polypropylene can also be degraded by its exposure to UV radiation from sunlight and it can also be oxidized at high temperatures. Different characterization techniques such as differential scanning calorimetry (DSC), Fourier transform infrared spectroscopy (FTIR), nuclear magnetic resonance spectroscopy (NMR), X-ray diffraction (XRD), contact angle measurements, X-ray 
photoelectron spectroscopy (XPS), water uptake experiment, etc., are applied to assess the biological degradation of plastics (Abdelaal et al., 2014).

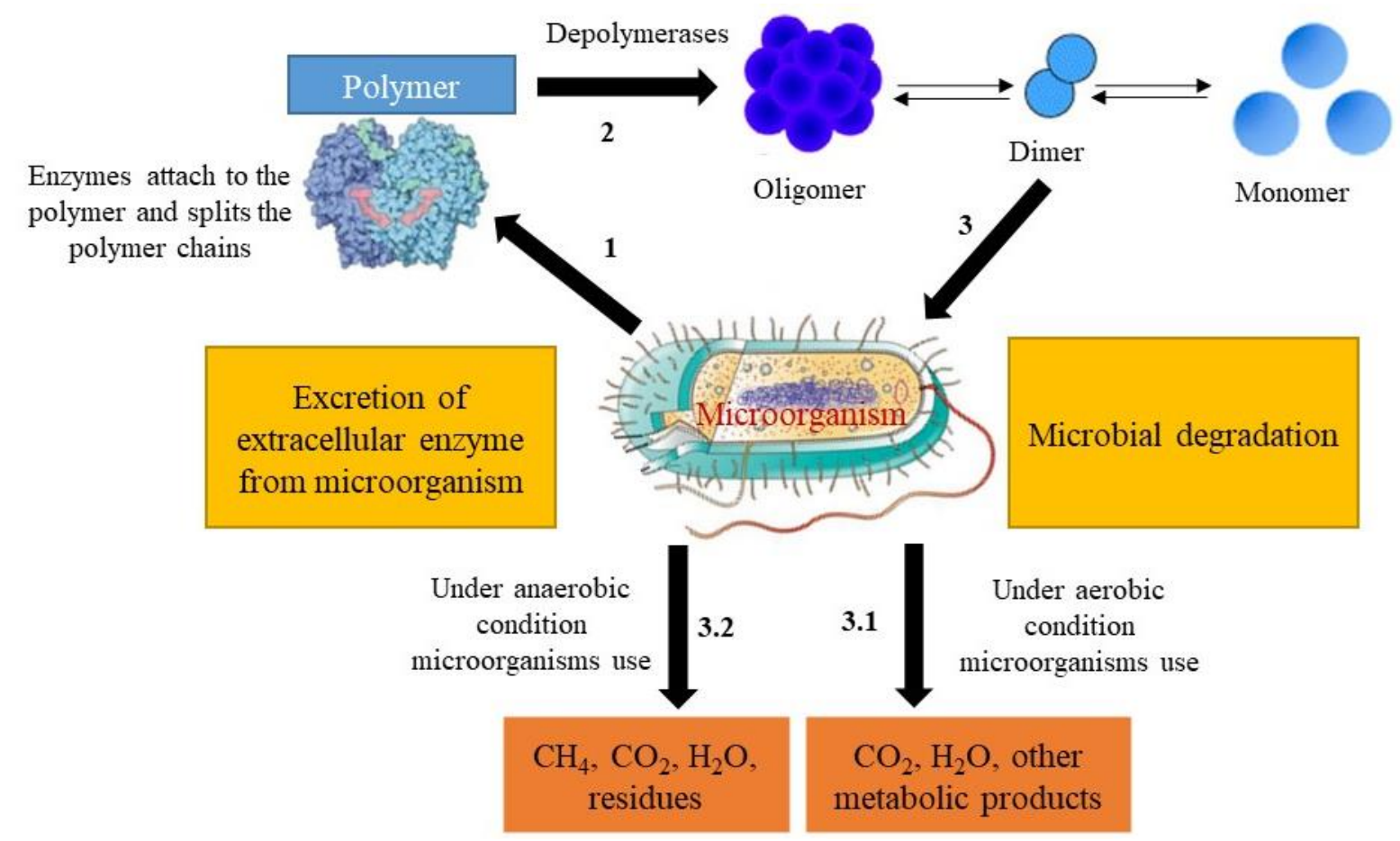

Fig. 4. Biodegradation mechanism of plastics under aerobic and anaerobic conditions (Fesseha \& Abebe, 2019)

Table 3. Microorganisms and corresponding enzymes for degradation of some plastics

\begin{tabular}{|l|l|l|l|l|}
\hline Plastics & Microorganism & Enzyme & $\begin{array}{l}\text { Simple } \\
\text { form }\end{array}$ & References \\
\hline Polyethylene & $\begin{array}{l}\text { Penicillium oxalicum \& } \\
\text { Penicillium chrysogenum }\end{array}$ & - & Biofilm & (Ojha et al., 2017) \\
\hline Polycaprolactone & Fusarium solani & Cutinase & - & (Murphy et al., 1996) \\
\hline Nylon & Phanerochaete chrysosporium & Manganese peroxidase & Oligomers & (Iiyoshi et al., 1998) \\
\hline Polyvinyl chloride & Pseudomonas fluorescens B-22 & - & Substrate & (Danko et al., 2004) \\
\hline Polystyrene & Rhodococcus ruber cereus \& & - & Biofilm & (Mor \& Sivan, 2008) \\
\hline Polypropylene & $\begin{array}{l}\text { Bacillus } \\
\text { Sporosarcina globispora } \& \text { et al., 2017) }\end{array}$ \\
\hline Polyurethane & Comamonas acidovorans & Lipases & - & (Helen \\
\hline
\end{tabular}

Nowadays, researchers and scientists are preparing polymeric materials using naturally available and degradable materials to substitute petro-based plastics to bio-based to some extent. Natural fibers-filled polymer composites have low mechanical and optical properties; however, they are more brittle in comparison to petrobased polymers/plastics (Bhandari et al., 2019). The polymer films such as cellulose, polylactic acid, polycaprolactone, etc., degrade faster in the soil compared to polyethylene, polyvinyl chloride, polystyrene (Bhandari et al., 2021a, 2021b).

\section{Plastic waste management during COVID-19 period}

There is maximum use of masks, gloves, and personal protective equipment (PPE) during COVID-19 by health workers, patients, and others (Prata et al., 2020; Rothan \& Byrareddy, 2020). These materials require proper management and disposal from an environmental point of view (Prata et al., 2020; Fan et al., 2021). Fig. 5 presents the schematic information and risks about plastic wastes management during the COVID-19 period (Fan et al., 2021). 
Fig. 5 represents the waste amount, change in waste amount, disposal rate, and timing (temporal), distribution (spatial), and infection risk (Fan et al., 2021). An improper management of the wastes may be a threat associated to COVID-19 infection (Bhandary et al., 2020; Tuladhar, 2020).

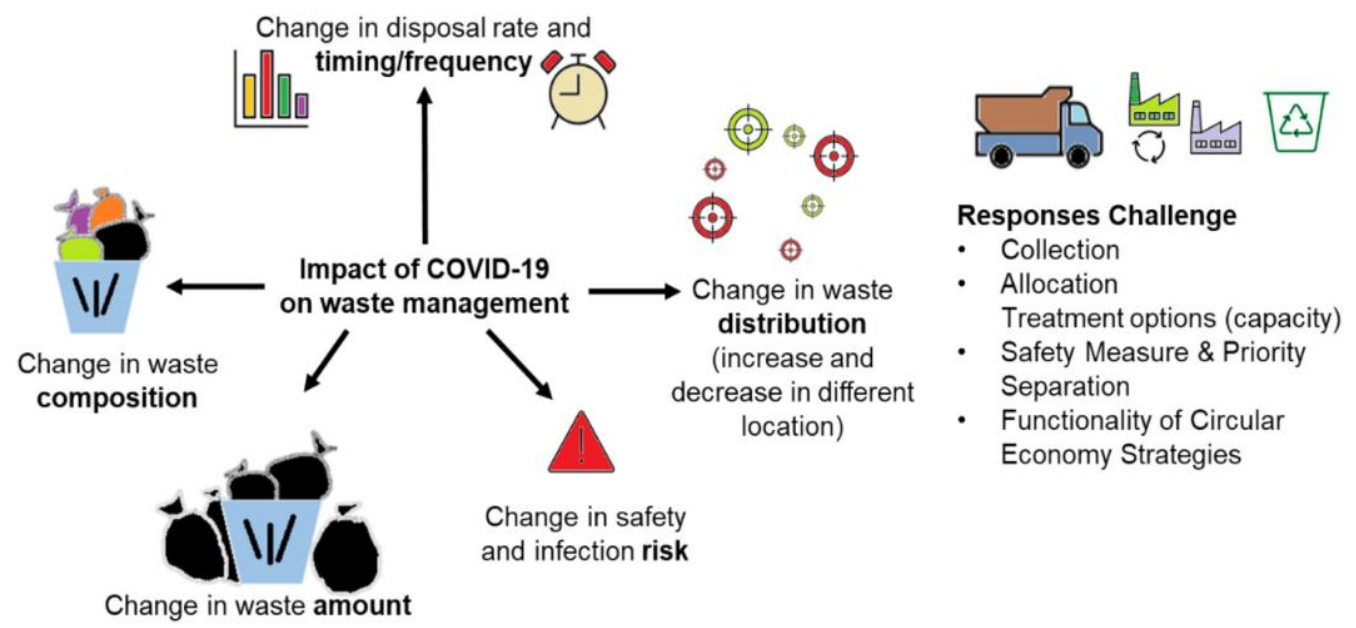

Fig. 5. Waste management scheme during COVID-19 period (with the waste amount, change in waste amount, disposal rate and time, distribution, infection risk impact, and challenges) (Fan et al., 2021)

\section{Synthesis of carbon dots (C-dots)}

Carbon dots are widely used in photo-catalysis for the decomposition of environmental pollutants, sensors and solar cells, bio-imaging, etc. (Aji et al., 2018). Nowadays, plastic wastes are also used for the preparation of C-dots. Carbon chains present in plastics (both bio and petrobased) undergo rearrangement during polymerization and carbonization processes to form C-dots (Kumal et al., 2018, Lauria \& Lizundia, 2020; Hu et al., 2021). C-dots have a tiny particle size $(<10 \mathrm{~nm})$ and possess fluorescence.

Polyethylene (PE), polystyrene (PS), polypropylene (PP), polyvinyl chloride (PVC), polyvinyl alcohol (PVA), polyethylene glycol (PEG), polyacrylic acid (PAA), polylactic acid (PLA), and some of the polymeric species are used as raw materials for the synthesis of $\mathrm{C}$-dots $(\mathrm{Hu}$ et al., 2021). Similarly, Aji et al. (2018) synthesized Cdots nanoparticles using waste plastic bags of polypropylene (PP) at $200{ }^{\circ} \mathrm{C}, 250{ }^{\circ} \mathrm{C}$, and $300{ }^{\circ} \mathrm{C}$. During the synthesis of $\mathrm{C}$-dots from solid wastes, biological by-products are formed. Hence, the synthesis of C-dots from polymers is also an environment-friendly method for plastics waste management (Lauria \& Lizundia, 2020).

\section{Economic and environmental aspects of plastic waste management}

The economy and technology play a vital role in plastic recycling and management (Renzini et al., 2009; Aho et al., 2007). Plastic recycling is further divided into material recycling and energy recovery (Pendern \& Yang, 2019) for which mechanical recycling is mostly preferred.
Nowadays, researchers have developed many techniques of modification of plastic wastes for their multiple-use and proper management. There is formation of alternative useful materials such as plastic bricks, road construction materials, etc., from the waste materials (Sasidharan et al., 2019). The development of such techniques helps to minimize the mass of plastic wastes releasing into the earth's crust as well as reduces the cost of useful materials production (Brasileiro et al., 2019; Horvath et al., 2018; Siddique et al., 2008).

Different countries such as India, the UK, the Netherlands, Ghana, Ethiopia, and South Africa have implemented the policy of using plastic wastes for road construction (Sasidharan et al., 2019). The waste plastics have been used in bituminous road construction, and addition at small amount ( 5-10 wt. \%) helps in significant improvement of strength, stability, fatigue life, and other desirable properties, longevity, and pavement (Sasidharan et al., 2019). Nepal has also developed some techniques (plastic fuel production, plastic tar for road construction) to utilize plastic waste and contribute to the control of environmental pollution (The Himalayan Times, 2018). It is almost impossible to ban plastic production immediately due to which sustainable plastic management is an urgent task.

\section{Current situation of plastic waste management in Nepal}

Daily use of plastic bags in Kathmandu (capital city) of Nepal is around 4,700,000 to 4,800,000 pieces (SWMRMC, 2004). In Nepal, $16 \%$ of urban waste comprises plastics, which is 2.7 tons of plastic garbage production daily (JICA/MLD, 2005). The daily plastic 
waste production in Nepal has increased continuously day by day (ICIMOD, 2018). Generally, solid wastes produced from daily life comprise of $56 \%$ organic wastes, $16 \%$ plastics, and $16 \%$ paper products, $3 \%$ glass, $2 \%$ metals, $2 \%$ textiles, $1 \%$ rubber and leather, and $4 \%$ others (Anderzen \& Blees, 2003). With the compost plant located at Teku, Kathmandu (capacity: 3 tons) closed in 1992, consequently increased, waste volume in the Gokarna landfill site, Kathmandu. Lack of roads or other infrastructures at the site resulted in vehicles dump waste near the Leachate pond. Due to inadequate compaction, a big landfill slide in 1992 covered the entire Leachate pond with waste (ADB, 2013). The current situation of waste plastics collection around the roadside in Kathmandu valley was shown in Fig. 6.

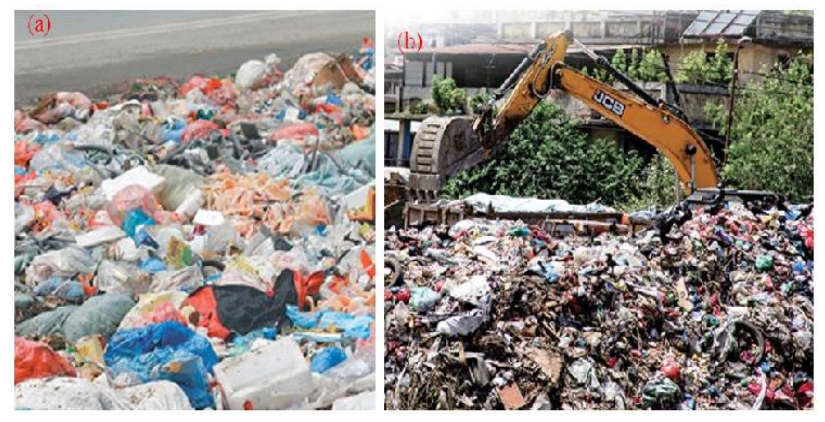

Fig. 6. Photographs of (a) unmanaged plastic waste in roads (b) waste piled at Teku landfill station, Kathmandu

Flash floods are common in Nepal due to plastic wastes clogging the rivers and streams in the mountains and hilly regions. The impact of what we do in the mountains is also felt downstream (Shrestha, 2010). They are neglected due to the absence of efficiency and inadequacy of the services. The container service, door-to-door collection, and roadside pick-up from open piles or containers are the types of collection service generally practiced in Nepal. The door-to-door collection is practiced by 24 municipalities; roadside pick-up from open piles is a prevailing practice, with 49 municipalities counting on plastics waste management (Babayemi et al., 2019).

Nepal Government together with corresponding ministries and authorities should bear the responsibilities regarding solid waste management (CBS, 1996). A huge volume of waste generated with practice of open burning, wastemixing practice, lack of reduction, reuse, and recycling and delayed and incomplete construction of a new landfill, informal and profit-oriented involvement of private waste collectors, were reported (Tuladhar \& Bania, 1997).

\section{Degradable/compostable plastics and their composite materials: an alternative}

Natural polymers, fibers, bio-plastics, biomaterials, green materials, degradable plastics, etc., are the possible alternatives to address all of the above-mentioned challenges. However, the properties of these polymers and materials cannot be perfectly suitable for applications. Therefore, the development of applications-oriented ecofriendly novel materials (such as composites, blends, etc.) based on these benign polymers can be a solution. An immediate action to collect the plastics waste scientifically and manage with best alternatives besides landfilling is needed. In India, thousands of kilometers of road have been constructed from waste plastics in recent years.

Furthermore, polylactic acid (PLA), starch, cellulose, polyglycolide (PGA), natural fibers, etc., are currently used as natural polymers (Adhikari et al., 2012a, 2012b; Bhandari, 2017; Mohanty et al., 2000; Bhandari et al., 2018; Wittel et al., 2003). Similarly, polybutylene adipate terephthalate (PBAT), polyhydroxyalkanoates (PHA), poly(alkylene dicarboxylate), etc., are degradable polymers, i.e. both on the soil surface and under burial (Mohanty et al., 2000). They undergo both enzymatic and chemical hydrolysis (degradation) (Wei et al., 2018). Biopolymers and bioplastics are degraded by UV radiation and microorganisms. Thus, from the economic and ecological/environmental point of view, plastic reuse, recycling, and their substitution by natural and degradable polymeric materials is an alternative to reduce nondegradable petroleum-based commodity plastics.

\section{CONCLUSION}

Current data shows a continuous growth of production and consumption of plastics/polymeric materials that cannot be controlled drastically. However, a huge amount of plastic wastes produced can be managed with suitably designed ecological and economical methods. Conversion of waste plastics into hydrocarbon fuel seems an excellent option for partial substitution of petroleum products. However, the economic perspective is to be considered and the technique has not been successful till now. The analyses of the above described different methods indicate that mechanical recycling can be an appropriate method for waste plastic management in the present context of Nepal.

Furthermore, the most common and daily used plastic products in Nepal are small to large plastic containers, packaging materials, polyethylene bags, thermosets, cables, insulating covers, etc. Most of these materials can be substituted using degradable polymers and their composites filled with degradable/compostable natural materials. Reducing the use of plastics and polymeric materials, reusing them many times, collecting the plastics in dustbins/drums separately, recycling as much as possible are the short-term steps to be implemented immediately. The promotion of research on degradable polymers, and the campaign for change in human habitual behavior on plastics use by proper education from schools 
to universities are necessary for long-term policies to combat polymeric wastes in the future. The use and promotion of degradable polymeric materials as a frontline state policy in this regard is recommended.

\section{REFERENCES}

Abdelaal, M. Y., Elmossalamy, E. H., \& Bahaffi, S. O. S. (2014). Modified polyethylene for synthetic wood application. Asian Journal of Chemistry, 26, 63136316.

Achilias, D. S., Roupakias, C., Megalokonomos, P., Lappas, A. A., \& Antonakou, E. V. (2007). Chemical recycling of plastic wastes made from polyethylene and polypropylene. Journal of Hazardous Materials, 149, 536-542.

ADB. (2013). Solid waste management in Nepal, current status, and policy recommendations. Asian Development Bank, 978-92-9254-232-0.

Adhikari, R., Bhandari, N. L., Causin, V., Le, H. H., Radusch, H-J., Michler, G. H., \& Saiter, J. M. (2012a). Study of morphology, mechanical properties, and thermal behavior of green aliphaticaromatic copolyester/bamboo flour composites. Polymer Engineering \& Science, 52(11), 2296-2303.

Adhikari, R., Bhandari, N. L., Le, H. H., Henning, S., Radusch, H-J., Michler, G. H., Garda, M-R., \& Saiter, J. M. (2012b). Thermal, mechanical, and morphological behavior of poly (propylene)/wood flour composites. Macromolecular Symposia, 315(1), 24-29.

Aguado, J., Serrano, D. P., \& Clark, J. H. (1999). Feedstock recycling of plastic wastes. The Royal Society of Chemistry Cambridge.

Aho, A., Kumar, N., Eranen, K., Salmi, T., Hupa, M., \& Murzin, D. Y. (2007). Catalytic pyrolysis of biomass in a fluidized bed reactor: influence of the acidity of H-beta zeolite. Process Safety and Environmental Protection, 85(B5), 473-480.

Aji, M. P., Wati, A. L., Priyanto, A., Karunawan, J., Nuryadin, B. W., Wibowo, E., Marwoto, P., \& Sulhadi, (2018). Polymer carbon dots from plastics waste upcycling. Environmental Nanotechnology, Monitoring \& Management, 9, 136-140.

Alla, M. M. G., Ahmed, A. I., \& Abdalla, B. K. (2014). Conversion of plastic waste to liquid fuel. International Journal of Technical Research and Application, 2, 29-31.

Almeida, D., \& Marques, M. F. (2016). Thermal and catalytic pyrolysis of plastic waste. Journal of Environment Management, Polimeros, 26(1), 44-51.
Al-Salem, S. M., Antelava, A., Constantinou, A., Manos, G., \& Dutta, A. (2017). A review on thermal and catalytic pyrolysis of plastic solid waste. Journal of Environmental Management, 198, 177-198.

Anderzen, C., \& Blees, V. (2003). Solid waste management in the city of Kathmandu, Nepal. Department of Technology, University of Kalmar, Kalmar.

Arandes, J. M., Erena, J., Azkoiti, M. J., Olazar, M., \& Bilbao, J. (2003). Thermal recycling of polystyrene and polystyrene- butadiene dissolved in a light cycle oil. Journal of Analytical and Applied Pyrolysis, 70, 747-760.

Azeez, T. O. (2018). Thermoplastic recycling: properties, modifications, and applications. Department of Biomedical Technology, Federal University of Technology, Owerri, Nigeria.

Babayemi, J. O., Norom, I. C., Osibanjo, O., \& Weber, R. (2019). Ensuring sustainability in plastics used in Africa consumption, waste generation, and projections. Environmental Science Europe, 5, 3160.

Balasundram, V., Ibrahim, N., Kasmani, R., Isha, R., Hasbullah, H., \& Ali, R. (2018). Catalytic upgrading of sugarcane bagasse pyrolysis vapor over rare earth metal loaded HZSM-5: effect of catalyst to biomass ratio on the organic compounds in pyrolysis oil. Applied Energy, 220, 787-799.

Beneroso, D., Bermudez, J. M., Arenillas, A., \& Menendez, J. A. (2015). Comparing the composition of the synthesis gas obtained from the pyrolysis of different organic residues for potential use in the synthesis. Journal of Analytical and Applied Pyrolysis, 111, 55-63.

Beyene, H. D. (2014). Recycling of plastic waste into fuels. International Journal of Science, Technology, and Society, 2(6), 190-195.

Bhandari, G., Pandit, R., \& Bhandari, N. L. (2018). Extraction and characterization of chitosan and preparation of nanocomposites with resorcinol formaldehyde resin. Journal of Nepal Chemical Society, 39, 53-61.

Bhandari, N. L. (2017). Comparative study of structure, morphology, and thermal properties of allo and cotton fibers on chemical modification. Journal of Nepal Chemical Society, 37, 37-42.

Bhandari, N. L., Bhandari, G., Bista, S., Pokhrel, B., Bist, K., \& Dhakal, K. N. (2021a). Degradation of fundamental polymers/plastics used in daily life: a review. Bibechana, 18, 240-253. 
Bhandari, N. L., Bista, S., Gautam, T. R., Bist, K., Bhandari, G., Subedi, S., \& Dhakal, K. N. (2021b). An overview of synthesis-based biomedical applications of hydroxyapatite nanomaterials. Journal of Nepal Chemical Society, 42(1), 64-74.

Bhandari, N. L., Dhungana, B. R., Lach, R., Henning, S., \& Adhikari, R. (2019). Synthesis and characterization of urea-formaldehyde eco-friendly composite based on natural fibers. Journal of Institute of Science and Technology, 24(1), 19-25.

Bhandari, N. L., Thomas, S., Das, C. K., \& Adhikari, R. (2012). Analysis of morphological and mechanical behaviors of bamboo flour reinforced polypropylene composites. Nepal Journal of Science and Technology, 13(1), 95-100.

Bhandary, S., Shrestha, S., Khatiwada, R., Shah, D., Munankarmi, N., Banjara, M., Parajuli, R., Manandhar, K., Adhikari, R., \& Tuladhar, R. (2020). Trend analysis, modeling and impact assessment of COVID-19 in Nepal. Journal of Institute of Science and Technology, 25(2), 1-8.

Boxiong, S., Chunfei, W., Binbin, G., \& Rui, W. (2007). Pyrolysis of waste tyres with zeolite USY and ZESM-5 catalyst. Applied Catalysis, 72, 150-157.

Brasileiro, L., Moreno-Navarro, F., Tauste-Martinez, R., Matos, J., \& Rubio-Gamez, Md. C. (2019). Reclaimed polymers as asphalt binder modifiers for more sustainable roads: a review. Sustainability, $11(3), 646$.

Braunegg, G., Bona, R., Schellauf, F., \& Wallner, E. (2004). Solid waste management and plastic recycling in Austria and Europe. Polymer-Plastic Technology and Engineering, 43, 1755-1767.

Canopoli, L., Fidalgo, B., Coulon, F., \& Wagland, S. T. (2018). Physico-chemical properties of excavated plastic from landfill mining and current recycling routes. Waste Management, 76, 55-67.

CBS. (1996). Urban population survey. His Majesty's Government of Nepal, Central Bureau of Statistics, Kathmandu, Nepal.

Cerqueira, M. A., Fabra, M., Lorena, J., Mayorga, C., Bourbo, A. I., Pastrana, L. M., \& Vicwnte, A. A. (2016). Use of electrospinning to develop antimicrobial biodegradable multilayer system: encapsulation of cinnamaldehyde and their physicochemical characterization. Food Bioprocess Technology. https://doi.org/10.1007/si1947-0161772-4

Chamas, A., Moon, H., Zheng, J., Qiu, Y., Tabassum, T., Jang, J. H., Omar, M., Scott, S. L., \& Suh, S. (2020). Degradation rates of plastic in the environment. ACS
Sustainable Chemistry and Engineering, 8, 34943511.

Cherubini, F., Bargigli, S., \& Ulgiati, S. (2009). Life cycle assessment of waste management strategies: landfilling, sorting plant, and incineration. Journal of Energy, 34, 2116-2123.

Ciriminna, R., \& Pagliaro, M. (2020). Biodegradable and compostable plastics: a critical perspective on the dawn of their global adoption. Chemistry Open Reviews, 9, 8-13.

Cunliffe, A. M., Jones, N., \& Williams, P. T. (2003). Pyrolysis of composite plastic waste. Environmental Technology, 24, 653-663.

Danko, A. S., Luo, M., Bagwell, C. E., Brigmon, R. L., \& Freedman, D. L. (2004). Involvement of linear plasmids in aerobic biodegradation of vinyl chloride. Applied Environmental Microbiology, 70(10), 60926097.

Demirbas, A. (2004). Pyrolysis of municipal plastic waste for recovery of gasoline range hydrocarbons. Journal of Analytical and Applied Pyrolysis, 72, 97102.

Dhokhikah, Y., \& Trihadiningrum, Y. (2012). Solid waste management in Asian developing countries: challenges and opportunities. Journal of Applied Environmental and Biological Science, 2(7), 329335.

Drzyzga, O., \& Prieto, A. (2018). Plastic waste management, a matter for the community. Microbial Biotechnology, 12, 66-68.

Dwivedi, P., Mishra, P. K., Mondal, M. K., \& Srivastava, N. (2019). Non-biodegradable polymeric waste pyrolysis for energy recovery. Heliyon, 5, 1-15.

Ejlertsson, J., Karlsson, A., Lagerkvist, A., Hjertberg, T., \& Sevensson, B. (2003). Effect of co disposal of wastes containing organic pollutants with municipal solid waste-a landfill simulation reactor study. Advances in Environmental Research, 7, 949-960.

Fan, Y. V., Jiang, P., Hemzal, M., \& Klemes, J. J. (2021). An update of COVID-19 influence on waste management. Science of the Total Environment, 754, $1-6$.

Fesseha, H., \& Abebe, F. (2019). Degradation of plastic materials using microorganisms: a review. Public Health Open Journal, 4(2), 57-63.

Goncalves, A. (2018). China has a new policy that will ban plastic waste: can it turn out to be something good. 
Gulab, H., Jan, M. R., Shah, J., \& Manos, G. (2010). Plastic catalytic pyrolysis to fuels as tertiary polymer recycling method: effect of process conditions. Journal of Environmental Science and Health, 45, 908-915.

He, M., Hu, Z., Xiao, B., Li, J., Guo, X., Luo, S., Yang, F., Feng, Y., Yang, G., \& Liu, S. (2009). Hydrogenrich gas from catalyst steam gasification of municipal solid waste: influence of catalyst and temperature on yields and product some position. International Journal of Hydrogen Energy, 34, 195203.

Helen, A. S., Uche, E. C., \& Hamid, F. S. (2017). Screening for polypropylene degradation potential of bacteria isolated from mangrove ecosystems in Peninsular Malaysia. International Journal of Bioscience, Biochemistry, and Bioinformatics, 7(4), 245-251.

Hidayah, N., \& Syafrudin (2018). A review of landfill management in the utilization of plastic waste as an alternative fuel. E3S Web of Conferences, 31, 1-6.

Hoornweg, D., \& Bhadatata, P. (2015). An analysis of European plastics production, demand, and waste data. Urban Development Series Knowledge Papers.

Hopewell, J., Dvorak, R., \& Kosior, E. (2009). Plastics recycling: challenges and opportunities. Philosophical Transactions of the Royal Society B, 264, 2115-2126.

Horodytska, O., Valdes, F. J., \& Fullana, A. (2018). Plastic flexible film waste management. Waste Management, 77, 413-425.

Horvath, B., Mallinguh, E., \& Fogarassy, C. (2018). Designing business solutions for plastic waste management to enhance circular transitions in Kenya. Sustainability, $10,1664$. https://doi.org/10.3390/su10051664

Howard, G. T. (2011). Microbial biodegradation of polyurethane, recent developments in polymer recycling. In A. Fainleib and O.Grigoryeva (Eds.) Recent developments in polymer recycling (pp. 215238), India: Transworld Research Network (ISBN: 978-81-7895-524-7).

Hu, Y., Li, M., Gao, Z., Wang, L., \& Zhang, J. (2021). Waste polyethylene terephthalate derived carbon dots for separable production of 5hydroxymethylfurfural at low temperature. Catalysis Letters. https://doi.org/10.1007/s10562-020-03484-6

Iiyoshi, Y., Tsutsumi, Y., \& Nishida, T. (1998). Polyethylene degradation by lignin-degrading fungi and manganese peroxidase. Journal of Wood Science, 44, 222-229.
Iwaya, T., Tokuno, S., Sasaki, M., Goto, M., \& Shibata, K. (2002). Recycling of fiber-reinforced plastics using depolymerization by solvothermal reaction with a catalyst. Journal of Material Science, 43, 2452-2456.

JICA/MLD (2005). The study on solid waste management for the Kathmandu valley. In Ujiie, T. (Team leader), CKV study report. Japan International Cooperation Agency (JICA) \& Ministry of Local Development (MLD), Kathmandu, Nepal.

Kaminsky, W., \& Zorriqueta, I. N. (2007). Catalytic and thermal pyrolysis of polyolefins. Journal of Analytical and Applied Pyrolysis, 79, 368-374.

Klink, R. E., \& Ham, R. K. (1982). Effect of moisture movement on methane production in solid waste landfill samples. Resources and Conservation, 6, 2941.

Kujawa, P., Schmauch, G., Vitala, T., Badia, A., \& Winnik, F. M. (2007). Construction of viscoelastic biocompatible films via the layer-by-layer assembly of hyaluronan and phosphorylcholine-modified chitosan. Biomacromolecule, 8, 3169-3176.

Kumari, A., Kumar, A., Sahu, S. K., \& Kumar, S. (2018). Synthesis of green fluorescent carbon quantum dots using waste polyolefins residue for $\mathrm{Cu}^{2+}$ ion sensing and live cell imaging. Sensors and Actuators B: Chemical, 254, 197-205.

Labelagr, A. (2006). Labeling agricultural plastic waste for valorizing the waste stream. Collective Research. Contract No. 516256-2.

Lauria, A., \& Lizundia, F. (2020). Luminescent carbon dots obtained from polymeric waste. Journal of Cleaner Production, 262, 1-9.

Lu, H., Sun, P., Zheng, Z., Yao, X., Wang, X., \& Chang, F. (2012). Reduction sensitive rapid degradable poly (urethane-urea)s based on cysteine. Polymer Degradation and Stability, 97, 661-669.

Marcilla, A., Gomez, A., Reyes-Labarta, J. A., \& Giner, A. (2003). Catalytic pyrolysis of polypropylene using MCM: 41: a kinetic model. Polymer Degradation and Stability, 80, 233-240.

Matlack, A. S. (2001). Introduction to green chemistry. New York: Marcel Decker.

Miskkolczi, N., Bartha, L., Deak, G., \& Jover, B. (2004). Thermal degradation of municipal plastic waste for the production of fuel like hydrocarbons. Polymer Degradation and Stability, 86, 357-366.

Mohanty, A. K., Misra, M., \& Hinrichsen, G. (2000). Bio fibers, biodegradable polymers, and biocomposites: 
an overview. Macromolecular Materials and Engineering, 276/277, 1-24.

Monsigny, L., Berthet, J-C., \& Cantat, T. (2019). Depolymerization of waste plastics to monomers and chemicals using a hydrosilylation strategy facilitated by Brookhart iridium (III) catalyst. Universite ParisSaclay, Gif-sur-Yvette, France.

Mor, R., \& Sivan, A. (2008). Biofilm formation and partial biodegradation of polystyrene by the actinomycete Rhodococcus ruber. Biodegradation, $19,851-858$.

Murphy, C. A., Cameron, J. A., Huang, S. J., \& Vinopa, R. T. (1996). Fusarium polycaprolactone depolymerase is cutinase. Applied and Environmental Microbiology, 62, 456-460.

Nath, A. (2014). Profitability and sustainability from waste management practices hotels and their impacts on the environment (An Ph.D. thesis). Jaypee Institute of Information Technology, India.

Ojha, N., Pradhan, N., Singh, S., Barla, A., Shrivastava, A., Khatua, P., Rai, V., \& Bose, S. (2017). Evaluation of HDPE and LDPE degradation by the fungus, implemented by statistical optimization. Scientific Reports, 7, 1-13.

Panda, A. K., Singh, R. K., \& Mishra, D. K. (2010). Thermolysis of waste plastics to liquid fuel a suitable method for plastic waste management and the manufacture of value-added products. Renewable and Sustainable Energy, 14, 223-248.

Pandey, B. K., Vyas, S., Pandey, M., \& Gaur, A. (2016). Characterization of municipal solid waste generation from Bhopal, India. International Scientific Organization, 2(3), 52-56.

Pendern K., \& Yang, L. (2019). Investigation of catalyzed thermal recycling for glass fiber reinforced epoxy using a fluidized bed process. Polymer Composites. https://doi.org/10.1002/pc.25213

Phaiju, S., Mulmi, P., Shahi, D., Hwang, T., Tiwari, A., Joshi, R., Pant, H., \& Joshi, M. (2020). Antibacterial cinnamon essential oil incorporated poly $(\mathcal{E}-$ caprolactone) nanofibrous mats: New platform for biomedical application. Journal of Institute of Science and Technology, 25(2), 9-16.

Pokhrel, M., Poudel, B., Aryal, R., Paudyal, H., \& Ghimire, K. (2019). Removal and recovery of phosphate from water and wastewater using metalloaded agricultural waste-based adsorbents: A Review. Journal of Institute of Science and Technology, 24(1), 77-89.
Prata, J. C., Silva, A. L. P., Walker, T. R., Duarte, A. C., \& Rocha-Santos, T. (2020). COVID-19 pandemic repercussions on the use and management of plastics. Environmental Science \& Technology, 54, 7760-7765.

Qiu, B., Deng, N., Zhang, Y., \& Wan, H. (2017). Application of industrial solid wastes in catalytic pyrolysis. Asia Pacific Journal of Chemical Engineering, 13(1), 1-14.

Ragaert, K., Delva, L., \& Geem, K. M. V. (2017). Mechanical and chemical recycling of solid plastic waste. Waste Management, 1-76. https://doi.org/10.1016/j.wasman.2017.07.044

Renzini, M., Sedran, U., \& Pierella, L. (2009). H-ZSM-11 and $\mathrm{Zn}-\mathrm{ZSM}-11$ zeolites and their applications in the catalytic transformation of LDPE. Journal of Analytical and Applied Pyrolysis, 86, 215-220.

Rigamonti, L., Grosso, M., Moller, J., Martinez, V., Magnani, S. \& Christensen, T. H. (2014). Environmental evaluation of plastic waste management scenarios. Resources, Conservation, and Recycling, 85, 42-53.

Rothan, H. A., \& Byrareddy, S. N. (2020). The epidemiology and pathogenesis of coronavirus disease (COVID-19) outbreak. Journal of Autoimmunity, $109, \quad 102433$. https://doi.org/10.1016/j.jaut.2020.102433

Sakata, Y., Uddin, M. A., \& Muto, A. (1999). Degradation of polyethylene and polypropylene into fuel oil by using solid acid and non-acid catalysts. Journal of Analytical and Applied Pyrolysis, 51, 135-155.

Sasidharan, M., Torbaghan, M. E., \& Burrow, M. P. N. (2019). Using waste plastics in road construction. Helpdesk Report 1-19.

Scaffaro, R., Maio, A., Sutera, F., Gulino, E. F., \& Morreale, M. (2019). Degradation and recycling of films based on biodegradable polymers. Polymers, 11, 651. https://doi.org/10.3390/polym11040651

Shabtai, J., Xiao, X., \& Zmierczak, W. (1997). Depolymerization liquefaction of plastic and rubbers. 1. Polyethylene, polypropylene, and polybutadiene. Energy and Fuels, 11, 76-87.

Shah, A. A., Hasan, F., Hameed, A., \& Ahmed, S. (2008). Biological degradation of plastic: a comprehensive review. Biotechnology Advances, 26, 246-265.

Shrestha, A., Poudel, B., Silwal, M., \& Pokhrel, M. (2019). Adsorptive removal of phosphate onto ironloaded Litchi chinensis seed waste. Journal of Institute of Science and Technology, 23(1), 81-87. 
Shrestha, R. M. (2010). Solid waste management in Kathmandu city, Nepal. Kathmandu Metropolitan, Kathmandu, Nepal.

Siddique, R., Khatib, J., \& Kaur, I. (2008). Use of recycled plastic in concrete. Waste Management, 28, 1835-1852.

Singh, S., \& Rawat, P. S. (2019). Biodegradation of plastic: an innovative solution to save human health and environment (pp. 435-461). In Handbook of research on environmental and human health impacts of plastic pollution. https://doi.org/10.4018/978-1-5225-9452-9.ch022

Sonawane, Y. B., Shindikar, M. R., \& Khaladkar, M. Y. (2015). Use of catalyst in pyrolysis of polypropylene waste into liquid fuel. International Research Journal of Environment Sciences, 4(7), 24-28.

SWMRMC/UN-HABITAT. (2008). Ten Steps for a clean city technical guidelines for solid waste management in Nepal (draft). Solid waste management and resource mobilization center. SWMRMC/UNHABITAT, Lalitpur, Nepal.

Tuladhar, B., \& Bania, A. (1997). Technical and economic analysis of Bhaktapur compost plant Nepal. Urban Waste Expertise Programme.

Tuladhar, R. (2020). Implication of monoclonal antibody for COVID-19 treatment. Journal of Institute of Science and Technology, 25(2), 133-140.
Walendziewski, J., \& Steininger, M. (2001). Thermal and catalytic conversion of waste polyolefins. Catalysis Today, 65, 323-330.

Wei, J., Yao, R., Ge, Q., Wen, Z., Ji, X., Fang, C., Zhang, J., Xu, H., \& Sun, J. (2018). Catalytic hydrogenation of $\mathrm{CO}_{2}$ to isoparaffins over Fe-based multifunctional catalysts. $\quad$ ASC $\quad$ Catalysis $1-39$. https://doi.org/10.1021/acscatal.8b02267

Wittel, F. K., Fischedick, J. S., Kun, F., Kroplin, B., \& Frieb, M. (2003). Discrete element simulation of transverse cracking during the pyrolysis of carbon fiber reinforced plastics to carbon/carbon composites. Computational Materials Science, 28, 115.

Woloseiwicz-Glab, M., Pieta, P., Sas, S., \& Grabowski, L. (2017). Plastic waste depolymerization as a source of energetic healing oils. E3S Web of Conferences, 14,02044.https://doi.org/10.1051/e3sconf/20171402 044

Yang, J., Miranda, R., \& Roy, C. (2001). Using the DTG curve fitting method to determine the apparent kinetic parameters of thermal decomposition of polymers. Polymer Degradation and Stability, 72, 455-461.

Zabeti, M., Nguyen, T. S., Lefferts, L., Heeres, H. J., \& Seshan, K. (2012). In situ catalytic pyrolysis of lignocellulose using alkali modified amorphous silica-alumina. Bioresource Technology, 118, 374381. 